\title{
Deconstruction in Performance for Audience Aesthetic Preference: An Experiment with Tyrone Terrence's "A Husband's Wife"
}

*Oluwatayo B. ISIJOLA

\begin{abstract}
Deconstruction, which allows subjective interpretation of literary texts, warrants performance text to assume a different meaning from the literary text for a change or an up-to-date signification. This article investigates African audience aesthetic preference for morality and value for human life, and it deploys deconstruction to re-order the unwholesome Euro-centric value that ñA Husbandôs Wifeò propagates. Having observed that the drama holds an unresolved óMedean-impulseô the study engaged a sample audience in the different performances of the drama for two consecutive days: day one performance was approached according to the dramatistô prototype, while the day two performance drew on the deconstruction of plot, style and characterization, to repose the unresolved factor, which rebates its aesthetic essence. The investigation combines the quantitative and qualitative methods for data capture and analysis, and thus deduced that the audience aesthetic preference was in favour of the day two performance. Hinging on the theory of deconstruction, the paper recommends that all such African plays bestowed with the shortcomings of African aesthetics, should be subjected to appropriate ádeconstructionôin the interest of drawing on audience preference for increased patronage and the development of theatre in Nigeria, while contributing to the enhancement of wholesome moral values.
\end{abstract}

Keywords: African aesthetic preference, óMedean-impulse,ô Performance deconstruction

\footnotetext{
* Oluwatayo B. ISIJOLA of the Department of Theatre and Media Arts,
}

Federal University, Oye-Ekiti, Nigeria Email: tayoisijola@yahoo.com 


\section{Introduction}

The theatre, as a collaborative art, harmonizes its constituent creative activities to communicate a social vision through performance engagement. Apart from the value of amusement or entertainment, which theatrical performances offer, they also educate and instruct the audience. That is why Hagher describes theatre as ña weapon of mass instruction, ò which reinforces the fact that theatre attains great essence when it serves as a platform for social mobilization (199). History records that the theatre of every society is themed by the happenings and issues that are peculiar to such society, and Shakespeare accedes in his play Hamlet (nd), as Hamlet addresses a group of actors:

é the purpose of playing, whose end, I both of first and now, was and is, to hold as áwere, the mirror up to nature; to show virtue her own feature, scorn her own image and the very age and body of the times and pressure. (1090)

Hence, the aphorism ñtheatre is the mirror of the societyò is true. Esslin attests to this when he states that ñthe theatre is the place where a nation thinks in public in front of itselfò (101). However, when the theatre takes on issues of universal essence; be it religious, moral, political or social, it treats it against the background of the uniqueness that is peculiar to the society the performance is made for. It follows that the theatre is not a tool that reflects social culture like a plain mirror does with the exactitude of impressions. Else, it may also achieve the proliferation of the ill aspects of the culture, instead of curbing them. Plato, thus worried about such counterproductive tendency, recommends that all performances, except ñhymns to the gods and praise to famous menò, should be banned from his utopian society (29-31).

Against this position, Aristotle, differs, and opines that tragedy (drama performance) seeks to deploy a number of artistic devices in the presentation of actions that exhibit incidences of ñpityò and ñfearò for the ñpurgationò of these ñemotionsò in the audience (39). It is such cathartic experience of audience members 
that the theatre have continuously deployed for social transformation Hence, Dasylvaôs remark that ñé the theatre serves as a veritable means and mirror by which it is either reflected or refractedò (96) alludes to the transformation propensity of the theatre. In other words, óaw materialsôfor the theatre are mirrored with altered appearance in other to achieve its objective. In The Marriage Coup (2013), Umukoro describes such deployment of theatre performances as ñrenovations by innovationò:

Director: é renovation by innovation. It is no longer just a matter of holding the mirror up to Mother Nature or merely painting society in its own colour. That would mean merely depicting her in such contorted images in a way that has become her lot today. It is now for us to conceive more artful ways of recreating models after our own heart. (19)

The charge above made to a crop of actors underscores the essential nature of theatrical performance, and its capacity to transform society. Thus, by refracting, the theatre manipulates images via a diminishing-magnifying device. Such devices, according to White, include the manipulation of ñspectatorship in either direction; increasing or decreasing aesthetic distanceò (21). Through the coordination of a director who harnesses the different arts of the theatre, performance materials sourced from the society are processed in appropriate dimensions, in order to fulfil theatre objectives to end users. To this end that Esslin claims that:

The peculiar nature of drama as an instrument of knowledge, or perception, thought, insight about society; its correctness and the fact that drama never makes an overt statement, that by its very nature it is always an experiment which always carries its own control-mechanism, its own verification, within it. (96) 
Consequently, this ñcontrol mechanismò serves to process real life incident(s) into aesthetically preferred performance, with which the theatre communicates its social vision. At any rate, theatre audience members do come with some pre-conscious notions that inform their aesthetic preference, and órerifyô the theatrical process. Thus, there is the need to consider the aesthetic preference of the target audience, foregrounded on their prejudgment for performance engagement. This article contends that Tyron Terrenceố A Husband's Wife is a true reflection of life happenings on the theme of marital infidelity in the Nigerian society, and considers the resolution of the drama, which ties to an unresolved ómadean-impulseô as an exactitude of real life. In so doing, it seeks to investigate audience aesthetic preference by experimenting with ñA Husbandôs Wifeò, in the variant performance of the drama.

\section{An Overview of "A Husband's Wife"}

Tyrone Terrence, a Jamaican-Nigeria creative artist, is a man of many parts, and has established himself as one of Nigeriấs contemporary playwrights. He has about twenty (20) plays to his credit, and A Husband's Wife is the most popular. The synopsis, plot summary and thematic thrust of the drama under investigation follows accordingly.

After twenty-two years of marriage, the union of Femi and his wife, Tomi is hit by an overwhelming mid-life crisis. This ensues while their two daughters and son are schooling and working abroad, respectively. When Femi invariably admits to infidelity after incessant accusations by his wife, he hinges his indulgence to her negligence: Femi blames her for devoting herself to her career, at the expense of their conjugal essence, and Tomi succumbs. She submits herself that night, but Femi is firm to hold on to his mistress. In spite of Tomi's pleas, Femi discloses that his mistress is pregnant, and he has to move out of their matrimonial home. The can of warm opens, when Tomi discovers from a hidden picture photograph that her husbandôs Mistress is the older friend of their daughter. Afterwards he poisons Femi and clears her conscience of guilt. 
A Husband's Wife is a domestic drama that consist of only two characters in the five-scene one-act play structure, and, it is set in the tastefully furnished modern bedroom of the couple- Femi and Tomi. The play has a simple plot that runs on climatic plot structure, and modelled after what Eugene Scribe describes as óvell-made playô

The plot of a well-made play regularly revolves about a secret known only to some of the characters; revealed at the climax, it leads to the downfall of the villain and the triumph of a hero. The action, which centre on conflict- especially a duel of wits between the hero and his opponent builds with increasing intensity through a series of (minor) reversals that culminates in the climaxes revelation scenes (Beckson and Ganz, 301).

The play opens with a point of attack, where Tomi presses hard husband for confession to an adulterous act, which her friend, Susan, had disclosed. Throughout the play, the secret, unveils in bits, and this serves to heighten the tension of dramatic action till climax. In Scene one, Femi admits to his lecherous life, reveals her mistress name as Linda. He discloses her age, which is twenty-two years younger than his, all to irk his wife. Tension accentuates in the second scene to a point of complication as Femi opens up further that Linda is pregnant. In spite of Tomi's hysteria in Scene three, she holds back to know more. When it gets unbearable, Tomi walk out of the bedroom to catch her breath. Upon her return in scene four, she stumbles at her husbandôs mistressô picture photograph, and identifies her as their daughterôs older friend. At that point, dramatic actions hit climax and begins to fall swiftly, as the play comes to an end in Scene five, where Tomi poisons her husband to death and alludes to Medea experience for justification.

The thematic trust of the play is topical in the contemporary African society, touching on the social problem of marital 
infidelity. The sub-themes of the play, which include love, hate, betrayal and revenge, tie up to enhance the playôs phenomenon, which the dramatist succinctly described as the ósychosociological study of aging marriageô $A$ Husband's Wife is styled for a realistic drama. This is evident in the prescribed setting, language, characters and dramatic happenings. The dialogism is smooth and lucid; underscoring characterization, delineating ideological positions and personality types. Noticeably, the dialogue is reminiscent of the conversations between Jason and Medea in Euripidesôs Medea (431BC), which, according to Worthern, is ñas though they were arguing in the courtroom or conducting a philosophical demonstrationò (64). The language is imbued in philosophical and psychological colours, and confrontational, persuasive, and emotional, being deployed in a rhythmically pleasing fashion. Also, the techniques effectively used in the play include: flashback, soliloquy, and language repetition.

\section{Conceptual Clarifications}

Amongst other things, aesthetics is an essential demand for the appreciation of all artistic endeavours. Adorno reinforces this when he states that ñactility seeks aesthetic quality in the effect that artwork has on the observer (10). As such, aesthetics is a vital element that distinguishes dramatic performance communication from other modes of communication. Lindôs supports this when he argues that:

Phenomenological analysis tends to show that an artwork must be aesthetic as well as meaningful. Without this further specification, what the artist has to say could not be distinguished from many non-artistic forms of communication. (117)

He further adduces that the aesthetic quality of a performance is a measure of how well the performance can endear and sustain audienceôs attention for a robust theatre experience (Lind, 119). It is probably in this regard that Adorno asserts that ñthere is much to be said for the idea that the dignity of artworks depends on the intensity of the interests from which we are vestedò (11). 
Aesthetics, as a branch of philosophy, is concerned with the subjective principles that define beauty in all relative disciplines; be it art or science. Beckson and Ganz note that there are two distinct views foregrounding the study of aesthetics: the objective and subjective views (7). The objective view holds the position that the quality that defines beauty is intrinsic to the object, and may elude its observer, whereas the subjective view consigns the indicators to beauty to observerôs preference. This study, however considers that performance aesthetics aligns with the subjective view of aesthetics. This position pivots from the meaning of the Greek, aisthetikos, which according to the Oxford Dictionary alludes to the sense of appreciation of beauty; giving that performance appreciation is the purview of audience members.

Therefore, holistic impartation of the audience in performance communication is the value of performance aesthetics, which is capable of holding and sustaining the attention of audience members, who in turn, respond with the vulnerability that makes performance engagement fulfilling. Such vulnerability, as noted by Brockett and Ball is what Taylor Coleridge refers to as the ñwilful suspension of disbeliefò (13). In fact, Kennedyôs position about the vulnerability of postmodern audience is that ñwilful suspension of disbeliefò amounts to the ñdouble negative that does not earn a positiveò, and thus posits that the disposition of the theatre audience is ñnot of suspending belief, but of creating belief in (sharing) the embodied intensity of the fiction through absorption with ito (214-215). Therefore, the keenness for aesthetics is essential performance engagement.

Accordingly, Johnson asserts that elements of aesthetics include luminosity (smoothness), clarity of forms and details, complexity of composition (suspense/tension/interest), balance and symmetry, among other things (34-35). Literally, these could be regarded as merely quantifiable attributes. However, aesthetics also consists in qualitative characteristics, which include the values system that constitutes the pre-conscious context of the percipient. According to Adedeji, ñthe Yoruba aesthetics postulates is ówa l'ewa', [é ] Character is cognate with ógoodôin its qualitative 
senseò (73). This implies that good character traits describe human beauty and essence. Johnson, in the same vein cites Vogelôs remarks, thus: ñit should be both beautiful and good, because it is intended not only to please the eyes but to uphold moral valuesò and explains why most African languages, such as Yoruba, deploy interchangeably the two words ñgoodò and r̃beautifulò, and for the same meaning (35). He further states that ñaesthetics is virtuous and propagates it [é ] aesthetics and vice or evil, seem not to have a meeting place; definitely not in the theatreò (Johnson, 98). Therefore, given the quintessential of aesthetics to drama performances, there is the need to capture the African aesthetic value in a performance designed for an African audience.

The researcher-experimentalist considers that the play, after climax, fails to conform to the essence of African aesthetics. After Tomi discovers that the mistress is a friend of the family, she poisons Femi to death and states, thus:

In ancient Greece there was a queen named Medea and her husbandôs name was Jasoné sacrifices? she sacrificed allé her conscience, her morality, her dignityé she killed so Jason would become king! But Jasoné who I believe is a distant relative of my husband betrayed Medeaôs love with another woman! Dear Godé poor Medea! Oh hell hath no fury than a woman scorned! In her rage she murders the princessé she kills all her children! And Jasoné poor Jasoné he could only ask ñWhyé ò? To which Medea replied ñTo break your hearté A fair price to pay to take away your smile.òAh tragedyé what tragedyé what a woman would do for love! The gods judged Medea and found her noté NOT GUILTY! They carried her away in a sun chariot because her cause was just, so my dear husbandé MY CAUSE IS JUST (Terrence, 33) 
Observably, Euripidesôinfluence is strong in the resolution of the Terrenceôs drama under investigation. The resolution is akin to the inordinate expression of intense, but repressed emotional feeling of Medea in EuripidesôMedea. In Medea, Euripides, treats a love-hate relationship between Medea and Jason, in a manner that Medea exhibits destructive emotion impulse (59-63). Such irrationality, as expressed in the deliberate act of murder as payback for hurt is what this study regards as óMedean-impulseô(. As Femiôs dies, Tomiôs statement, which brings the play to an end, is: ñI love you Femi. I will always love youé but I will rather see you dead than imagine you in the arms of another womanò (Terrence 34). This manifestation of the óMedean-impulseôis antiAfrican aesthetic, and it is not appropriate for African audience engagement, if it is tenable in other society. For Terrence to express the óMadean-impulseô he could have moderated the dramatic action with the doctrine of ópoetic justiceô as did Williams Shakespeare in Othello (1603), Jean Racine in Phaedra (1677) and Henrik Ibsen in Hedda Gabler (1891). Indeed, John Denisôremark in Beckson and Ganz that any literature work that deflects from poetic justice is either ñan empty amusement or a scandalous and pernicious libel upon the government of the world (207), is instructive here. With poetic justice, óbalance and symmetryô which are essential elements of aesthetics, are maintained in a drama.

However, there is a point of departure between drama as a play-text, and as performance, which subordinates the whims of a dramatist to the influence of the director and enables the director to re-order a performance in context. The directorôs duty, which includes, harnessing a collaboration of various artistic inputs towards achieving a common goal, goes along with possible ádeconstructionô Such inputs, as dramatist, choreography, designs, dance, acting and singing, among others, are harmonised by the director in some sort of unity to express the vision of a drama performance. Pickering recognizes such harmony that he refers to as ñartistic unityò as being exemplified in George II, Duke of SaxeMeiningen (1826-1914), for which he is credited as the father of 
modern directing (156-157). Given that the dramatist initiates the pre-performance artistic process by authoring the play text, which serves as a baseline for the performance preparation, his artistic input is however not sacrosanct.

Modern philosophy underscores the fact that there is no revered text cast in watertight fitting. In fact, there is the recommendation that authors should be detached from their work the moment it gets to the end user. This grants the readers the benefit of subjective interpretation. Such authorial detachment is probably what made Barthes to demand for the ñdeathò (silence) of the author when he states that ñthe text henceforth is written and read so that in it, on every level, the author absents himselfò (4). For this reason, Foucault remarks also that ñthe writer is reduced to nothing more than the singularity of his absence; he must assume the role of a dead man in the game of writingò (207). Such detachment endows the reader with what Beckson and Ganz recognise as an ñacknowledged and controlled subjectivityò (224), which endow a sense of reading pleasure that enables the selfcapacity for subjective interpretation. Thus, Barthes succinctly declares that ñthe birth of the reader must be ransomed by the death of the authorò (6). For the reader to experience reading pleasure, and the enabled capacity to fill the gaps of subtexts, authorial detachment is vital.

In the same vein, a director takes liberty to engage in an informed re-ordering of a play-text, without the interference of the dramatist, when the need arises. Interestingly, such re-ordering of drama by the director, at performance, has given most dramatists the benefit of improving the play-text. Amadi attests to this in the forward to the reprinted version of his play while expressing gratitude to the production team (n.p). It is in this connection that Pickering considers the director as a ñcritic interpreterò (161). However, some dramatists hold their published work jealously against subjective interpretation. Thompson supports this view when he states that ñanxiety about interpretation has been evident in writers on the art for a number of yearsé (121), and an instance that attests to this, which African scholars have largely criticized as 
unnecessary, is the warning which Soyinka issues the to-bedirectors of Death and the King's Horseman when he states that:

é one of the obvious alternative structures of the play would be to make the district officer the victim of a cruel dilemma. This is not to my taste and it is not by chance that I have avoided dialogue or situation which could encourage this. No attempt should be made in production to suggest it (6-7).

Based on Barthesô and Foucaultôs philosophy, such warnings are needless as any play text can be exposed to the subjective interpretation of the director, who seeks to convey a particular social vision to an audience. Thus, when a director engages the performative elements for textual interpretation, he does so taking into cognizance of the aesthetic preference and a timely social vision for the target audience. As such, the director can re-derive a vision, different from the dramatistôs, for the drama. Johnson upholds this when he states that:

The playwrightô vision simply stands for his perception of views of the world in a particular play, under a particular theme/preoccupation é if the director applies the sub-textualistic aesthetics in the interpretative process, the vision rediscovered, may very well go beyond the dimension anticipated by the playwright (29-30).

Granted that creativity is the currency of the theatre, and given that the demand for authorial-detachment is applicable to play texts, the director is vested with the privilege of sub-textual interpretation, and this may reflect in any of the intrinsic elements of the play; be it language, style, genre, plot, music, spectacle and techniques. Herein, the theory of deconstruction comes to play.

The term áleconstructionô was introduced Jacques Derrida (1930-2004), and the theory draws on the philosophy of Barthes and Foucault, regarding their position about authorial detachment 
from literary works, to engender the possibilities of subjective interpretations and meanings. Gnanasekaran suggests this when he remarks that Derrida was a brilliant student of Michel Foucault (211). It is a poststructuralist theory in which Derrida underscores the arguments of Ferdinand de Saussure (1857-1913), who contended with the ideal of semiotics in stating that ñthere is no absolute equivalence between the óignifierô and the concept óignifiedò and concludes that ñlanguage was not a system of positive differentiation (the identity of each signifier laying not in any essence of its own but in it being distinguishable from others)ò (Beckson and Ganz 57). On this basis, Derrida propounds that since signification is not absolute, that the reader of a text can indulge in an open ended interpretation of language to derive subjective meanings, which implies a óe-constructionôof meaning from the text, thereby rendering the text áleconstructedô(414).

Gnanasekaran notes that the ñTheory of Deconstructionò touches ñon the innate, interior inconsistencies in language and elucidationé ò, and further explains that its application ñncorporates all other related necessities of building radically and tenaciously, and/or contains both obliteration and improvement in itself giving space for illuminationé ò (212). Therefore, deconstruction can serve as a device through which a readers or an interpreter of literary text, re-constructs new meanings from a text, in an informed manner that is most applicable to a social context. However, Johnson warns that the departure, which may be occasioned by áleconstructionôñshould come as an end product of deliberate construction and not as a result of accidental destruction (36)ò. This experiment of this study, which included the production of Tyron Terrenceôs A Husband's Wife in both the ñslavishò and ñinterpretativeò directorial approaches; the later involving a certain measure of deconstruction, to investigate audience satisfy audience preference in a play text that is otherwise flawed by its resolution.

\section{Performance Deconstruction of Tyron Terrence's $\boldsymbol{A}$ Husband's Wife}

At the level of performance, A Husbands Wife is a preferred for adirector/producer in the contemporary Nigerian theatre. Apart 
from its topicality, its appeals to the convenience of production are noteworthy. The economy of cast and setting makes it suitable for low-budget production. It is a play that is capable of inspiring the director, actors and designers towards a robust creative engagement. However, the dramatist preference at the resolution is of serious concern to this study. The performance, as directed by the researcher, held on Thursday $5^{\text {th }}$ May and Friday $6^{\text {th }}$ May 2016 at the educational theatre facility of the Department of Theatre and Media Arts, Federal University Oye-Ekiti, with Ijeoma Izuogu as Tomi and Isaac Gondo as Femi on both days. The Thursday performance was somewhat ñslavishò in approach. This approach is what Johnson describes a $s$ ñ faithful follower of the playwrightò (97-98). With very minimal and necessary adjustments, the play was produces as prescribed by the dramatist on Day One.

However, Day 2 performance witnessed a óleconstructionô of the resolution scene, which bothered strongly on style, reflective in acting, scenography, light design, costuming and the introduction of a subordinate characters, all in the resolution scene. The performance at resolution was treated to surrealism, after the similitude of August Strindbergôs A Dream Play (1901). The Dream play attempts to ñimitate the inconsequential, yet transparent logical shape of a dreamò, and Strindberg holds that in the dream play ñeverything can happen, everything is possible and probableò (158). Thus, the Day 2 performance needs not ádeconstructôthe plot and dialogue of the drama severely, hence the óMedea-impulseôcould be transposed to a ódream playô where all actions are permissive. During the performance, Femi experiences a heightened emotion in the dramatic action that precedes the climactic scene to prepare grounds for what Freud describes as ñLatent Dream Thoughtò (151). According to the playtext, after engaging in stretch of conflicts and complications occasioned by charges and counter chargers, allegations and defences, augments and all odds that work up the couple, the disengage, and Tomi walks away out of the room, Femi heaves a heavy sigh to express an overwhelming state that will can foreshadow a turning point. In this, he demonstrates self- 
realisation, and turns to speaks to the audience as in a manner that can pivot a turning point:

(Tomi exits leaving Femi staring at the closed door)

FEMI (Turns to face audience) What does a man do when he realizes that he canô find what he fell in love with in the woman he fell in love with? What does he do when he wakes up to discover that the object of his affection has become the subject of his affliction? (Pause) You may not believe it but I have discovered a darker truthevery married man is sitting on a Volcano! And one dayé one day sooné

Lights fade out.(Terrence, 26)

The ñLights fadesò prescribed above delays. Femi is in a pensive mood, and with the weariness of heart, he goes to lay in bed, and after covering his entire body with the Duvet, lights fade. The light out serves not just for scene transition, but also for passage of time to occasion the dream scene, and to allow for necessary technical adjustments. At light out, a subordinate character with the same body structure as the actor playing Femi goes under the Duvet, while Femi goes backstage. Light comes up and loud soars rends the air from the subordinate character buried under the Duvet, to depict such sleeping dimension where dreaming can possibly take place.

Lights come up and reveals the state as it was in the previous scene. Femi is in a deep sleep. He dreams and snores loudly. Lights get dim slightly, and the dreamlike effects of flickers and colour fill the stage. Tomi enters in an attire different from her previous. She is carrying a display board and suspends it across the bed. It bears inscriptions and images which reads:

BY SLEEPING, MAN LEARNS HOW TO DIE. 
ADIEU, FEMI.

Tomi sits and on a chair in the room and looks on. Femi enters from within, appearing in different attire too. He hands a bag on his shoulder, and drags a big box by the handle. When he notices Tomi's presence, he affronts her (Production Book, 19).

It is glaring to the audience that the last scene of the Day One performance plays out as dream in Day Two. The murder scene occurs in Femi's dream, and as Tomi's runs her vindicating monologue, the special effect fades to darkness. She ends it all with a farewell chant that gets the backing of a óchorus of Wishesô while darkness still fills the stage. Then a loud scream and panic attack comes on as lights illuminates the stage to establish the end of the dream.

TOMI (Chants with ritualistic tempo) Adieu!

CHORUS OF WISHES. (from backstage) Adieu!

TOMI. (Chants rises to the high key) Adieu!!

CHORUS OF WISHES. (Raises key) Adieu!!!

TOMI. (Chants falls to a lower key) Adieu!!!

CHORUS OF WISH. (Drops key) Adieu!

Lights come up to reveal Femi as he struggles in his sleep. He throws off the blanket and pillow, while shouting and struggling hard to wake up.

FEMI. Jesus!!!

He wakes with a loud scream.

(He sits up in a moment and sighing heavily. As he checks for the display board. Tomi enters in the initial costume, unnoticed. Femi's phone rings again, and as he turns he notices that his wife refuses to take the call in spite of her propinquity. Femi summons courage and answers the call)

FEMI. (Sighing heavily) Linda, Lindaé please donâ complainé I am at a brink right now. I cannot 
make it to your end tonighté and I donâ think I will anymore. Yesé yeh. Yes, you were righté we should not have started out. There we are at last. I must nip it in the board like you already suggested. I must fix things with my wife before they get out of handé I already lied to her that my mistress is pregnanté You may want to follow up on the vacation arrangementé I canô join you anymoreé I knowé Spend the resources in your coffers judiciouslyé I hate to say it, but- ohé tooé , bye and Farewell. (Sighs and hangs on)

With a sense of achievement, Tomi stretches her hands in his Direction. Femi walks into her embrace and they exchange a kiss.

BLACK OUT (Production Book, 23).

\section{Findings}

Keen observations made on the audience at both the Day One and Day Two performances are key to the findings of this study. Day One performance was breath-taking, and it witnessed an exhilarating response of excitement from the audience from the first scene. However, it was observed that the resolution for Day One, tragic as it was, did not produce the kind of effect that a tragedy, such as Othello, would produce. The Day One performance left the audience with question such as ñwhy? Ònd ñwhat is next?Q̂ in spite of the rousing ovation that trailed the performance. The performance did not occasion what Aristotle regard as ñpurgation of emotionsò (39), which Beckson and Ganz describe as a purifier of dangerous feelings (284). Interviewees expressed a common concern that the ending of the Day One performance was deficient because it ñpromotes jungle justice.ò A female member of the audience Titilayo Adeosun in an interview with the researcher on 5 May, 2016 stated that ñFemi should have been given the chance to come back to his senses (change), 
because he might still change. Besides, his death is a loss and will benefit nobodyò.

The Day Two experience was different. The researcherdirector ensured that all audience members in the sampled population, who saw Day One performance, were present for Day Two. The excitement was more, perhaps, because the sampled population for the survey, where present to see the same play on a second run. The áleconstructionôdeployed to re-interpret the last scene for the Day Two performance was a preferred option for most audience members, including males and females. A female respondent, Lilian Bakare in an interview with the researcher on 6 May, 2016 attested to this when she stated that ñthe second day performance communicated the message better, perhaps because of the additional components that presented the ending bit as a dream. Ò The results of the survey of the sampled population reveal in figure A (below), an assessment of the predominant response to spousal infidelity in Nigeria:
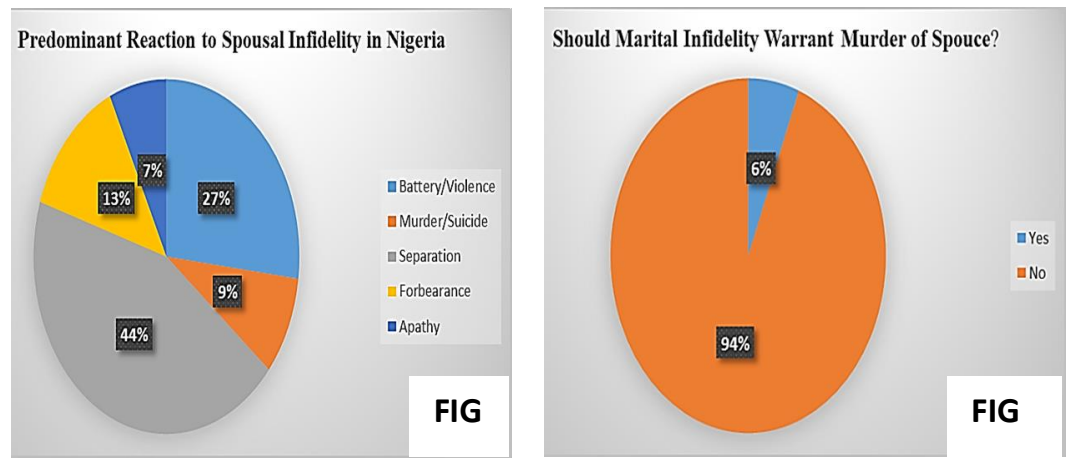

The result in figure $\mathrm{B}$ (above) answers the investigation on the conditionality that may warrant/justify the killing of an unfaithful spouse by the offended partner. Therefore, going by individual preferences, $76 \%$ of the sampled audience favoured forbearance and forgiveness, which reinforces the suggestion made by Titilayo Adeosun, while other suggestions include: separation- 9\%, divorce- $6 \%$, consultation and counselling- $4 \%$, and prayer and 
divine intervention- 3\%. Further information on the sampled audience demographics is provided below.

\section{Socio-Demographic Statistics of Sampled Population}

\begin{tabular}{|c|c|c|}
\hline AGE BRACKET & FREQUENCY & PERCENT (\%) \\
\hline $16-25$ & 58 & 58.0 \\
\hline $26-35$ & 11 & 11.0 \\
\hline $36-45$ & 18 & 18.0 \\
\hline $46-55$ & 11 & 11.0 \\
\hline $56+$ & 2 & 2.0 \\
\hline Total & 100 & 100.0 \\
\hline OCCUPATIONAL STATUS & FREQUENCY & PERCENT (\%) \\
\hline University Staff & 36 & 36.0 \\
\hline University Student & 59 & 59.0 \\
\hline Others & 5 & 5.0 \\
\hline Total & 100 & 100.0 \\
\hline SEX & FREQUENCY & PERCENT (\%) \\
\hline Male & 36 & 36.0 \\
\hline Female & 64 & 64.0 \\
\hline Total & 100 & 100.0 \\
\hline MARITAL STATUS & FREQUENCY & PERCENT (\%) \\
\hline Single & 68 & 68.0 \\
\hline Married & 31 & 31.0 \\
\hline Widowed & 1 & 1.0 \\
\hline Total & 100 & 100.0 \\
\hline RELIGION & FREQUENCY & PERCENT (\%) \\
\hline Christianity & 86 & 86.0 \\
\hline Islam & 14 & 14.0 \\
\hline Total & 100 & 100.0 \\
\hline
\end{tabular}

\section{Further Discussion/Conclusion}

Even though this study is not a defence for moral bankruptcy of African husbands who are unfaithful in marriage, it is worth mentioning that infidelity in the African traditional society is an act tolerated and expressed in different dimensions. The practices of 
polygamy and the keeping of concubine(s) are earliest forms of infidelity in African families, which women seem to admit as part and parcel of matrimony. Among the Ngwa, an Igbo community in Nigeria, when a wife identifies her husbandô mistress, she freely addresses her as Iko dim (my husbandôs concubine). This may be considered as one of Africaốs patriarchal strains, but it infers that African wives, by nature were more tolerant and accommodative to spousal lecherous indulgence. The survey result from this study, which favours forbearance and forgiveness, also validates this inference. Respondents, who suggest the need to engage in dialogue, and seek, counselling by way of consultations, were premised on the basis of experience, and the African optimistic value, as they attest that many almost-broken unions were reordered on this account.

However, modernisation reveals that indulgence in infidelity is not only unfair, but it exposes the reckless individual to a deluge of risks. Recent happenings in Nigeria attest to the fact that the reaction of the offended partner to cases of spousal infidelity has been heightened to unfathomable ends. They have constituted regular news items in the Nigerian media. Such headlines as ñMan Butchers Wife Over Infidelity in Deltaò (Information Nigeria, online), ñMan Kills Cheating Wife and Attempts Suicideò (Information Nigeria, online), ñMan Slit Wifeôs Throat over Alleged Infidelity and Poisons Himselfò (Punch Newspaper, online), and ñLecturer Killed by his Wife and his Brother for Allegedly Having a Girl Friendò (Olufamos.com, online), were popular examples across the new media in 2016. While these media, including print, and electronic, are at their best propagating these life-happenings as new items, the theatre medium must expediently create more artful means of engaging the public with the life-happenings in fictitious manner for social change. This is important to the essence of performance communication, and the need to engender optimum audience consciousness. Important, too, it is an established bias that murder should not be an option for a hurt spouse who seeks to vent anger. The manifestation of ñMedian-impulseô is irrational to the African sensibility. For Africans, murder is a loss to humanity, thus, it is not aesthetic for African art to propagate it. 


\section{Works Cited}

Adorno, Theodor. Aesthetic Theory. Ed. Gretel Adorno and Rolf Tiedemann. London: Continuum, 1997. Print.

ñAestheticsò. Encyclopaedia Britannica: Encyclopaedia Britannica Ultimate Reference Suite. Chicago: Encyclopaedia Britannica, 2014.

ñAestheticsò. Oxford Dictionary. $\quad$ Web. 9 May 2017 <www.oxforddictionary.com>

Akomolafe, Niyi, ñMan Butchers Wife over Infidelity in Delta.ò Information Nigeria. Web.5 August 2016 http://www.informationng.com/2015/09/man-butchers-wifeover-infidelity-in-delta.html

Alhassan, Amina ñWhy we Need to Revive the Theatres,ò Web. 6 August 2017

http://www.dailytrust.com.ng/weekly/index.php/magazinecover/13799-why-we-need-to-revive-the-theatres-tyrone-eterrence.

Amadi, Elechi. ñForwardò Peppersoup and Road to Ibadan. Ibadan: Onibonoje Publishers, 1977. Print.

Aristotle. ñOn the Art of Poetryò Classical Literary Criticism Trans. T.S. Dorsch. New York: Penguin Books Ltd, 1965. (p31-75). Print.

Barthes, Roland. ñThe Death of the Authorò Ubu Web Paper (1-6). Trans. Richard Howard.

Web. 6 Feb, 2016 http://www.tbook.constantvzw.org/wpcontent/death authorbarthes.pdf

Beckson, Karl and Ganz, Arthur. Literary Terms: A Dictionary. $3^{\text {rd }}$ ed. New York: The Noonday Press, 1994. Print.

Brockett, Oscar and Ball Robert. The Essential Theatre. California: Wadsworth-Thomson. 2004. Print.

Dasylva, Ademola O. Studies in Drama. Ibadan: Stirling-Horden Publisher, 2004. Print.

Esslin, Martin. An Anatomy of Drama. London: Maurice Temple Smith Ltd., 1976. Print.

Euripides, ñMediaò Ten Plays by Euripides. Trans. Moses Hadas and John Mclean. New York: Bantan Books, 1981. (p93-67). Print. 
Foucault, Michel. ñWhat is an Authorò. Aesthetics, Method, and Epistemology. Ed. James D. Faubion. Trans. Robert Hurley et al. New York: The New Press, 1998. 205-222. Print.

Ugolo, Chris . ñDance Pedagogy in Nigeria: Experience and Challenges.ò Perspectives in Nigerian Dance Studies. Ed. Yerima, A. Bakare, R. and Udoka. A. Lagos: Caltop Publications Ltd., 2007. 45-54. Print.

Freud, Sigmund. Introductory Lectures on Psychoanalysis. Trans. James Strachey. Ed James Strachey and Angela Richards. Middlesex: Penguin Books Ltd. 1962. Print.

Gnanasekaran R. ñAn Introduction to Derrida, Deconstruction and Post-Structuralism.ò International Journal of English, Literature and Culture. 3.7 Web 22 August, 2017. http://www.academicresearchjournals.org/IJELC/PDF/2015/J uly/Gnanasekaran.pdf

Hager, Iyorwuese. Weapon of Mass Instruction. Ibadan: Spectrum Books Ltd., 2004. Print.

Hanafi, Afeez. ñMan Slit Wifeô Throat over Alleged Infidelity, Poisons Self.ò Punch Newspaper.Web.6 August 2016 http://punchng.com/man-slit-wife-throat-overallegedinfidelity-poisons-self/.

Shakespeare, Williams. ñHamlet: Prince of Denmark.ò The Complete Works of Williams Shakespeare. New York: Avenel Books. N.d. Print.

Johnson, Effiong. Aesthetics: The Dialectics and Theatrics of Theatre and Communication. Lagos: Concept Publications, 2004. Print.

Johnson, Effiong. Vision Towards a Mission: The Art of Interpretative Directing. Lagos: Concept Publication Limited, 2003. Print.

Kennedy, Dennis. The Spectator and the Spectacle: Audience in Modernity and Post Modernity. Cambridge: Cambridge University Press, 2009. Print

Lind, Richard. ñThe Aesthetic Essence of Art.ò The Journal of Aesthetics and Art Criticism 50.2 (1992): 116-29. Print.

Ugolo, Chris. ñDance Pedagogy in Nigeria: Experience and Challenges.ò Perspectives in Nigerian Dance Studies. Ed. Yerima, A. Bakare, R. and Udoka. A. Lagos: Caltop Publications Ltd., 2007. 45-54. 
Kanjo, Daniel. ñMan Kills Cheating Wife, Attempts Suicide.ò Information Nigeria.Web.4 August 2016 https://www.informationng.com/2014/10/man-kills-cheatingwife-attempts-suicide-in-delta.html

McConachie, Bruce. Engaging Audience: A Cognitive Approach to Spectating in the Theatre. New York: Palgrave Macmillan, 2008. Print.

Olufamos.com. ñLecturer Killed by his Wife and her Brother for Allegedly Having a Girlfriend.ò 26 July 2016 http://www.olufamous.com/2016/06/lecturer-killed-by-hiswife-her.html

Pickering, Jerry. Theatre: A Contemporary Introduction. $3^{\text {rd }}$ ed. Minnesota: West Publishing Company, 1981. Print.

Plato. ñThe Republicò Dramatic Theory and Criticism: Greeks to Grotowski. Ed. Dukore

Bernard F. New York: Holt, Rinehart and Winston Inc., 1974. 12-31. Print.

Posner, Michael I. Cognition: An Introduction. Illinois: Scott, Foresman and Company, 1973. Print.

Production Book. ñFUOYE Performance of A Husband's Wife: May 2016ò. Unpunished

Soyinka, Wole. ñAuthorôs Note.ò Death and the King's Horseman. London: Eyre Methuen Ltd., 1975.6-7. Print.

Strindberg, August. ñAuthorôs Note to A Dream Play (1901)ò. Modern Theories of Drama. Ed. George W. Brandt. Oxford: Oxford University Press, 1998. 158-59. Print.

Terrence, Tyrone. ñA Husbandôs Wife.ò Provide place and time (unpublished)

Thompson, James. Performance Affects: Applied Theatre and the End of Effect. New York: Palgrave Macmillan, 2011. Print.

Tuner, Victor. The Anthropology of Performance. New York: PAJ 
Publication, 1988. Print

Umukoro, Julie. The Marriage Coup. Ibadan: Kraft Books Ltd., 2013. Print.

White, Gareth. Audience Participation in Theatre: Aesthetics of the Invitation. New York: Palgrave Macmillan, 2013. Print.

Worthen W.B. The Wadsworth Anthology of Drama. $4^{\text {th }}$ ed. London: Cengage Leaning, 2004, Print. 